\title{
Population densities of understorey birds across a habitat gradient in Palawan, Philippines: implications for conservation
}

\author{
N.A.D. Mallari, N.J. Colla R, D.C.Lee, P.J.K. McGowan, R. Wilkinson \\ and S.J. MARSDEN
}

\begin{abstract}
There is widespread concern for many understorey and ground-dwelling bird species in the Philippines that appear intolerant of forest alteration. We present density estimates for 18 key bird species in old growth forest, advanced and early secondary growth and active cultivation within the Puerto Princesa Subterranean River National Park in Palawan. Six species were not recorded in cultivation and the abundance of these and several others increased along the successional gradient from cultivation to old growth forest. Eleven species, including five endemics and three of four threatened species, had highest density estimates in old growth forest. However, several species had high density estimates in the heavily disturbed habitats and every habitat type held highest densities of at least one of the bird species. The commonest habitat association across the bird community was a preference for areas containing large trees, indicating the importance of retention of such trees in allowing suitable ground and understorey microhabitats to persist. Old growth forests have the highest conservation value for Palawan's endemic birds and, while some species thrive in the anthropogenic habitats that occur within the Park, the present extent of cultivation and associated successional stages within its boundaries should not be increased. We caution against extrapolation of the abundance figures from the Park to the whole island but we suggest that population sizes for the threatened species are likely to be much greater than previously thought. We urge authorities to strengthen management within the protected area network in Palawan to ensure survival of key species.
\end{abstract}

N.A.D. MALlari Fauna \& Flora International-Philippines Programme, c/o The International Institute of Rural Reconstruction, Y.C. James Yen Centre, Silang, Cavite 4118, Philippines. E-mail aldrin.mallari@fauna-flora.org

N.J. Collar BirdLife International, Cambridge, UK

D.C. LEE Harapan Rainforest, c/o Dept. of Conservation Science, RSPB, Sandy, UK

P.J.K. McGowAN World Pheasant Association, Newcastle University Biology Field Station, Heddon on the Wall, UK

R. Wilkinson North of England Zoological Society, Chester Zoo, Chester, UK

S.J. Marsden Division of Biology \& Conservation Ecology, School of Science \& the Environment, Manchester Metropolitan University, Manchester, UK

Received 19 November 2009. Revision requested 7 February 2010.

Accepted 26 March 2010.
Keywords Bird abundance, forest quality, management planning, management zones, Palawan, Philippines, protected area, threatened species

\section{Introduction}

The loss and alteration of forests through logging and agriculture represents major threats to tropical biodiversity, with tropical forests holding a greater number of threatened bird species than any other habitat (BirdLife International, 2003). The pace of land-use change in SouthEast Asia is of special concern, with huge areas being clearfelled, or turned over to logged forest, small-scale agriculture, or large-scale monocultures such as oil palm (Fitzherbert et al., 2008). These land uses are associated with declines in bird species richness or abundance (Peh et al., 2005; Scales \& Marsden, 2008) and there is particular concern for the plight of understorey and ground-dwelling forest birds. These are considered to be especially intolerant of microhabitat changes (Thiollay, 1992; Lambert \& Collar, 2002; Diaz et al., 2005; Marsden et al., 2006) and poor dispersers between habitat fragments following habitat degradation (Barlow et al., 2006).

The Philippines has suffered widespread deforestation and, across the archipelago, $<20 \%$ of original forest cover remains (Posa et al., 2008). Consequently, the country has 21 Endangered or Critically Endangered forest bird species (BirdLife International, 2010). Unfortunately, capacity to study biodiversity within the Philippines is low, and this has led to an acute lack of quantitative data on abundances and how environmental change may affect them. Only a few density estimates (Lee \& Marsden, 2008) and encounter rates (Posa \& Sodhi, 2006) have been produced for Philippine birds. Nevertheless, such information is key to assessing extinction risks across the avifauna as a whole and, at a local level, to provide clear conservation prescriptions to management authorities (Mallari, 2009).

In this study densities were estimated for 18 key bird species across a range of habitats in the Puerto Princesa (formerly St Paul's) Subterranean River National Park on Palawan, Philippines. The species chosen for our study include 17 understorey and ground-dwelling species (eight of which are endemic and six threatened or Near Threatened; Table 1), plus the endemic and Vulnerable Palawan hornbill Anthracoceros marchei. Density estimates were 
Table 1 Key bird species in Puerto Princesa Subterranean River National Park (Fig. 1) for which abundance information is presented, with their endemism, IUCN Red List status (IUCN, 2010) and characteristic habitats.

\begin{tabular}{|c|c|c|c|}
\hline Species & Endemism & Red List status ${ }^{1}$ & Habitat $/ \mathrm{s}^{2}$ \\
\hline Tabon megapode Megapodius cumingii & & LC & LF, CS \\
\hline Red junglefowl Gallus gallus & & LC & $\mathrm{LF}$ \\
\hline Palawan peacock-pheasant Polyplectron napoleonis & Palawan & VU & LF \\
\hline Black-backed kingfisher Ceyx erithaca & & LC & LF \\
\hline Palawan hornbill Anthracoceros marchei & Palawan & VU & $\mathrm{LF}$ \\
\hline Red-bellied pitta Pitta erythrogaster & & LC & LF \\
\hline Black-naped monarch Hypothymis azurea & & LC & FE \\
\hline Blue paradise-flycatcher Terpsiphone cyanescens & Palawan & NT & $\mathrm{LF}$ \\
\hline Rufous-tailed tailorbird Orthotomus sericeus & & LC & $\mathrm{FE}, \mathrm{M}$ \\
\hline Ashy-headed babbler Trichostoma cinereiceps & Palawan & LC & $\mathrm{LF}$ \\
\hline Melodious babbler Malacopteron palawanense & Palawan & NT & $\mathrm{LF}$ \\
\hline Falcated wren-babbler Ptilocichla falcata & Palawan & VU & $\mathrm{LF}$ \\
\hline Pin-striped tit-babbler Macronus gularis & & LC & LF, FE \\
\hline White-vented shama Copsychus niger & Palawan & LC & $\mathrm{LF}$ \\
\hline Palawan flycatcher Ficedula platenae & Palawan & VU & LF \\
\hline Palawan blue-flycatcher Cyornis lemprieri & Palawan & NT & $\mathrm{LF}$ \\
\hline Mangrove blue-flycatcher Cyornis rufigastra & & LC & $\mathrm{LF}$ \\
\hline Citrine canary-flycatcher Culicicapa helianthea & & LC & LF, MAF \\
\hline
\end{tabular}

${ }^{1}$ VU, Vulnerable; NT, Near Threatened; LC, Least Concern (IUCN, 2001)

${ }^{2}$ CS, coastal scrub; FE, forest edge; LF, lowland forest; M, mangroves; MAF, mid-altitude forest (from Dickinson et al., 1991)

compared across a habitat disturbance gradient from old growth forest, through advanced and early secondary growth to active cultivation to identify the species that are least tolerant of forest conversion. The habitat associations of individual species were then examined to determine the habitat features that most strongly indicate species presence or absence. Results were then used to refine assessments of conservation status for the species and to inform management planning within the Park and policy across Palawan as a whole.

\section{Study area}

Puerto Princesa Subterranean River National Park, a UNESCO World Heritage Site and an Important Bird Area, spans a $210 \mathrm{~km}^{2}$ mosaic of habitats including active cultivation, lowland dipterocarp and molave forests, karst forest and montane forest on Palawan (Anda \& Tabangay, 2004; Fig. 1). Land-use and land-cover interpretations (DENR-NAMRIA \& JAFTA, 1992-2000) indicate that $44 \%$ (c. $92.4 \mathrm{~km}^{2}$ ) of the Park comprises lowland forest, $32 \%$ steep-sloping forest above $700 \mathrm{~m}\left(67.7 \mathrm{~km}^{2}\right), 15 \%$ karst formations with sparse vegetation $\left(31.3 \mathrm{~km}^{2}\right)$, and $9 \%$ either grassland and cultivated areas or mangrove and coastal areas $\left(18.6 \mathrm{~km}^{2}\right)$. Owing to the inaccessibility of karst formations and high-elevation forests, sampling was only possible up to c. $700 \mathrm{~m}$ altitude.

The Park and its surroundings are the ancestral lands of the Batak and Tagbanua peoples but include settlements of people from other islands. There are three villages within the Park, the smallest of which contains 98 households at a density of 4 people per $\mathrm{km}^{2}$ and the largest 415 households $\left(17\right.$ people per $\mathrm{km}^{2}$ ), and the highest population density is in the third village, with 32 people per $\mathrm{km}^{2}$ (Anda \& Tabangay, 2004). Continuous rapid population growth of $5.4 \%$ is expected in the future (UNDP-GEF-SGP, 2003), with $65 \%$ of this growth attributed to actual population growth and $35 \%$ due to net immigration.

\section{Methods}

\section{Habitat surveys}

From January to May 200638 transect lines each $2 \mathrm{~km}$ long (total effort $=152 \mathrm{~km}$ ) were surveyed within the Park to cover a full range of habitat and disturbance gradients. Each transect was marked every $50 \mathrm{~m}$ to assist in recording broad habitat types (cultivation, early secondary growth, advanced secondary growth and old growth) and in assigning bird records to habitat along transects. Cultivation was defined as areas with active or recently abandoned farmland and included grasslands, brushlands, agricultural plots and small orchards with fruit trees $\leq 4 \mathrm{~m}$ tall. Within the Park agricultural holdings are small and generally non-intensive, and contain a diversity of crops both within and between holdings. Early secondary growth forests are areas of newly regenerating forest $(<20$ years old) dominated by saplings and other small- to medium-sized trees. Advanced secondary growth forests are c. 20-40 years old, have a less dense understorey and are dominated by medium to large trees. The age of secondary growth within the Park was ascertained primarily through oral histories given by indigenous people 


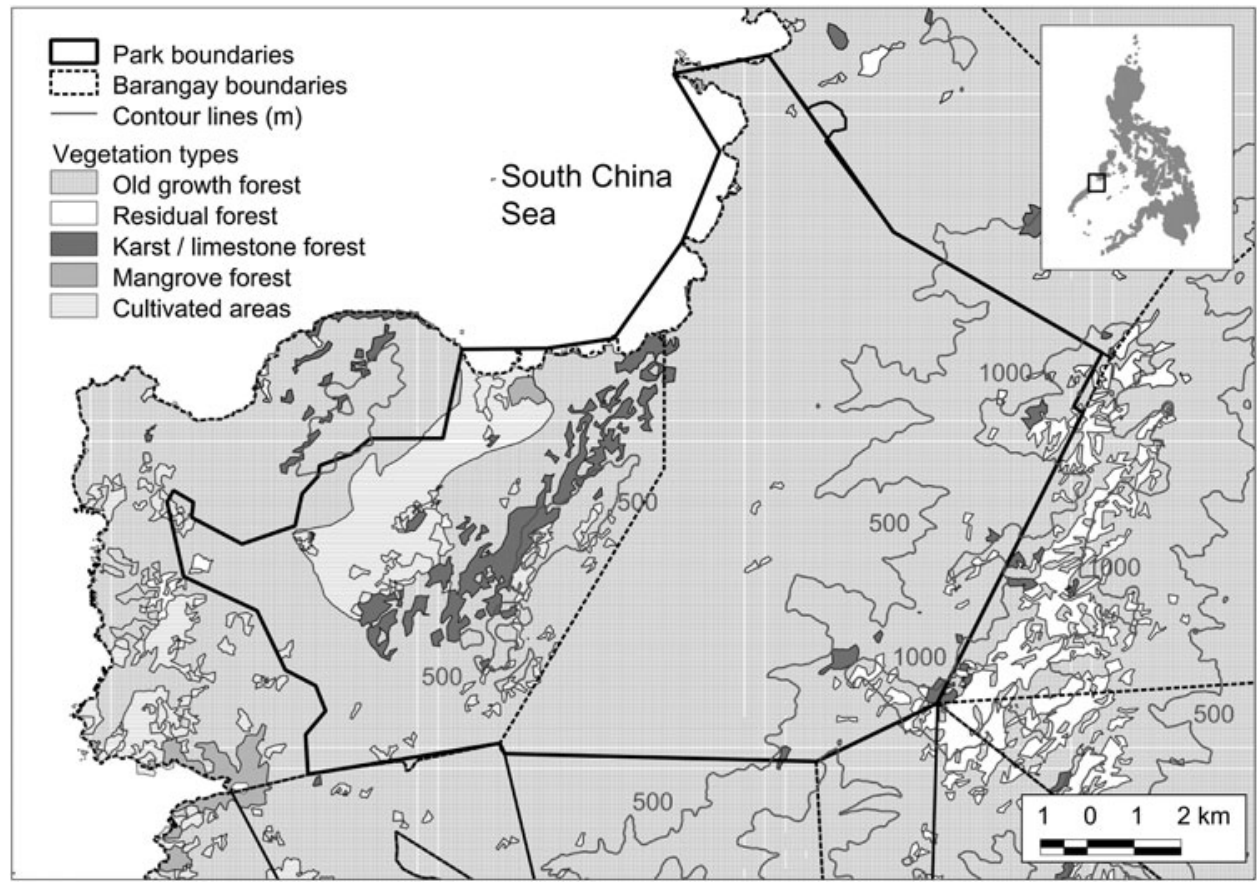

Fig. 1 Location map of Puerto Princesa Subterranean River National Park showing Park boundaries and habitat types. Sources: DENR-NAMRIA \& JAFTA (1992-2000) and DENR-PAWB et al. (2004).

and Park staff, augmented by biological information obtained during the survey. Old growth (i.e. primary forest or forest $>40$ years old) forests are dominated by large to very large trees and have a less complex understorey compared to early secondary growth and advanced secondary growth.

Habitat sampling points were positioned every $250 \mathrm{~m}$ along transects. At each sampling point the following physical and structural habitat variables were sampled: (1) altitude using a global positioning system and adjusted by cross-referring UTM coordinates to a digital elevation model; (2) gradient using a clinometer; (3) diameter at breast height $(\mathrm{DBH})$ of the five nearest trees, with each tree then assigned to a size class $(>80-160 \mathrm{~cm} \mathrm{DBH}$ or $>160$ $\mathrm{cm} \mathrm{DBH})$; (4) percentage ground cover of leaf litter and herbaceous plants (vegetation $<1 \mathrm{~m}$ height) in four $1 \mathrm{~m}^{2}$ quadrats positioned randomly in each quarter; (5) number of rattan clumps and small trees $>2 \mathrm{~m}$ tall and with $10-80 \mathrm{~cm}$ $\mathrm{DBH}$ within a $20-\mathrm{m}$ radius.

\section{Bird surveys}

Point counts are commonly used for bird surveys in tropical forest (Lee \& Marsden, 2008). In this study, however, with bird encounter rates from pilot studies relatively low, the terrain comparatively easy to traverse and vegetation relatively open, we preferred the line transect method to estimate bird densities (Buckland et al., 2001). Transects were $2 \mathrm{~km}$ long and walked at a speed of $1 \mathrm{~km} \mathrm{~h}^{-1}$, only in dry conditions and when wind speed was not a hindrance to bird detection or activity. For each encounter with a perched bird or group of birds, the species, number of individuals in the group, and horizontal perpendicular distance from transect to bird or to centre of a single-species group (measured with a laser rangefinder) were recorded. It is difficult to determine group size of birds detected aurally only in dense vegetation, so the mean group sizes for visual contacts were substituted for these unknown values (Lee \& Marsden, 2008). All bird surveys began at dawn, when bird activity is usually highest (Blake, 1992). Transects were repeated on a different day in the reverse direction to minimize bias attributed to route direction (Karr, 1981) and bird activity and time of day (Jones, 1998).

\section{Data analysis}

Values of each of the nine habitat variables were compared across the four habitat types. Data were not normally distributed, and transformation was not always straightforward, and therefore differences across habitats were tested with Kruskal-Wallis non-parametric ANOVAs using SPSS v. 16 (SPSS, Chicago, USA).

Bird records from the two walks along each transect were pooled to calculate densities (expressed as individuals per $\mathrm{km}^{2} \pm \mathrm{SE}$ ) using Distance v. 5.o (Thomas et al., 2006). All data were right-truncated at $50 \mathrm{~m}$ to remove any outlying records, improve model fit and reduce the likelihood of a bird encounter being assigned to an incorrect habitat type (Buckland et al., 2001). Where necessary further right-truncation of the data was undertaken at distances where detection probability was $\leq$ o.1 (Buckland et al., 2001). Uniform, half-normal, hazard rate and negative 
exponential functions with adjustments were considered, and the model yielding the lowest Akaike's Information Criterion value (AIC; Akaike, 1974) for a given set of data was selected as the best fit for those data (Buckland et al., 2001). Post-stratification of the data by habitat type enabled comparison of abundance estimates and differences in detectability in different habitats within the Park. If the combined AIC values for individual habitat detection functions was greater than the post-stratified AIC for those data, the post-stratified parameters were used as the more reliable estimate of abundance (Buckland et al., 2008). Density estimates are presented as the number of individuals per $\mathrm{km}^{2} \pm \mathrm{CV}$ (coefficient of variation; the SE of the density estimate expressed as a percentage of it).

The habitat associations of individual bird species were examined by relating their presence or absence around habitat plots to the altitude, gradient, mean tree diameters, the numbers of trees with DBH $<80,>80-160$ and $>160$ $\mathrm{cm}$, number of rattan clumps, and percentage herb and ground cover. Analyses were performed only for bird species recorded around $\geq 15$ plots. Generalized linear models (GLMs) with logit links and binomial error distributions were constructed for each species in $R$ ( $\mathrm{R}$ Development Core Team, 2009). The nine habitat variables were entered and removed until a minimum acceptable model was reached, where removal of additional variables resulted in increase in the model's AIC value.

\section{Results}

\section{Definition and comparison of habitat types}

There were significant differences in all habitat measures across habitat categories (Table 2), indicating some biological basis to the groupings and their use. Patterns amongst overstorey habitat features were as expected, with average tree diameter, and density of medium-sized (80$160 \mathrm{~cm} \mathrm{DBH})$ and large trees $(>160 \mathrm{~cm} \mathrm{DBH})$ all decreasing from old growth through advanced secondary growth and early secondary growth to cultivation. Numbers of rattans followed this pattern, being common in old growth and usually absent in cultivation. These differences, consistent with those of many studies, indicate a disturbance gradient running from old growth and advanced secondary growth (high biomass forest with relatively full canopy) through to early secondary growth and cultivation, which are increasingly open-canopied and lacking in large trees. Percentage herb layer was similarly relatively low in old growth and advanced secondary growth but much higher in both cultivation and early secondary growth, indicating a much fuller herbaceous layer in the latter two habitats, facilitated by a broken canopy. Ground-level cover was high only in cultivation and sapling density $(<20 \mathrm{~cm})$ was low only in cultivation, this habitat being the only one largely devoid of trees and with most vegetation restricted to ground and low levels. Altitudinal ranges of survey plots in three of the four habitat types were similar but plots in advanced secondary growth tended to be at higher altitudes (c. $60 \mathrm{~m}$ higher but still at elevations where forest can be classed as lowland). However, Table 2 reveals an increasing tendency for forests to be altered on flatter ground. Cultivation is also more likely to be practised at lower altitudes within the Park, while steep and inaccessible areas are those where old growth forest is most likely to remain.

\section{Bird density estimates}

Density estimates are presented for 17 understorey and ground-dwelling species plus the canopy-dwelling Palawan hornbill (Table 3). Density estimates were reasonably precise, as demonstrated by the CV being $<50 \%$ of the density estimate in 34 species/habitat cases. Six species were not

TABle 2 Medians (and inter-quartile ranges) of habitat measures recorded in four habitat types in Puerto Princesa Subterranean River National Park (Fig. 1). Mean DBH is of the five nearest trees with a DBH $>80 \mathrm{~cm}$. Differences across habitats were tested with a Kruskal-Wallis non-parametric $\operatorname{ANOVA}(H)$.

\begin{tabular}{|c|c|c|c|c|c|}
\hline & Old growth & Advanced secondary growth & Early secondary growth & Cultivation & $H$ \\
\hline Altitude (m) & $123(135)$ & $190(324)$ & $129(192)$ & $61(130)$ & $33.9^{* *}$ \\
\hline Gradient $\left(^{\circ}\right)$ & $20(26)$ & $18(25)$ & $10(22)$ & $8(15)$ & $21.9^{* *}$ \\
\hline \multicolumn{6}{|l|}{ Overstorey } \\
\hline Mean DBH $(\mathrm{cm})$ & $201(94)$ & $170(94)$ & $132(91)$ & $94(82)$ & $154.0^{\star *}$ \\
\hline Trees $>160 \mathrm{~cm}$ & $6(5)$ & $4(5)$ & $2(4)$ & $0(2)$ & $68.4^{* *}$ \\
\hline Trees $>80-160 \mathrm{~cm}$ & $12(10)$ & $6(6)$ & $4(4)$ & $1(4)$ & $91.0^{* *}$ \\
\hline \multicolumn{6}{|l|}{ Understorey } \\
\hline No. of rattan clumps & $20(25)$ & $12(18)$ & $9(19)$ & $0(3)$ & $62.0^{\star *}$ \\
\hline$\%$ herb cover & $30(35)$ & $30(40)$ & $50(55)$ & $63(42)$ & $24.2^{\star}$ \\
\hline$\%$ ground cover & $40(32)$ & $33(35)$ & $35(40)$ & $70(65)$ & $11.8^{*}$ \\
\hline Trees $10-80 \mathrm{~cm}$ & $84(55)$ & $80(58)$ & $75(64)$ & $16(48)$ & $51.9^{* *}$ \\
\hline
\end{tabular}

${ }^{\star} \mathrm{P}<0.001 ;{ }^{* *} \mathrm{P}<0.0001$ 
TABLe 3 Density estimates $\left(\mathrm{km}^{-2} \pm \mathrm{CV}\right)$ for 18 ground, understorey and conservation-important bird species in four habitat types (Table 2) in Puerto Princesa Subterranean River National Park.*

\begin{tabular}{lccrc}
\hline Species & $\begin{array}{c}\text { Cultivation } \\
(\mathrm{n}=28 \mathrm{~km})\end{array}$ & $\begin{array}{c}\text { Early secondary } \\
\text { growth }(\mathrm{n}=88 \mathrm{~km})\end{array}$ & $\begin{array}{r}\text { Advanced secondary } \\
\text { growth }(\mathrm{n}=70 \mathrm{~km})\end{array}$ & $\begin{array}{r}\text { Old growth } \\
(\mathrm{n}=28 \mathrm{~km})\end{array}$ \\
\hline Tabon megapode & $0.5 \pm 115$ & $0.1 \pm 161$ & $0.5 \pm 36$ & $0.8 \pm 57$ \\
Red junglefowl & $0.6 \pm 116$ & $1.2 \pm 38$ & $1.0 \pm 76$ & $2.4 \pm 44$ \\
Palawan peacock-pheasant & $\mathrm{NR}$ & $5.4 \pm 37$ & $10.8 \pm 38$ & $20.3 \pm 64$ \\
Black-backed kingfisher & $2.8 \pm 73$ & $2.9 \pm 76$ & $3.7 \pm 61$ & $8.6 \pm 88$ \\
Palawan hornbill & $\mathrm{NR}$ & $9.6 \pm 38$ & $13.8 \pm 35$ & $19.6 \pm 39$ \\
Red-bellied pitta & $\mathrm{NR}$ & $1.5 \pm 74$ & $4.9 \pm 47$ & $4.2 \pm 54$ \\
Black-naped monarch & $9.4 \pm 60$ & $10.8 \pm 33$ & $8.4 \pm 39$ & $12.2 \pm 59$ \\
Blue paradise-flycatcher & $11.8 \pm 50$ & $4.2 \pm 34$ & $7.3 \pm 35$ & $13.8 \pm 43$ \\
Rufous-tailed tailorbird & $19.6 \pm 31$ & $15.0 \pm 21$ & $21.9 \pm 14$ & $29.6 \pm 28$ \\
Ashy-headed babbler & $47.4 \pm 38$ & $29.6 \pm 25$ & $3.1 \pm 23$ & $20.3 \pm 40$ \\
Melodious babbler & $9.0 \pm 84$ & $10.3 \pm 34$ & $4.8 \pm 50$ & $7.0 \pm 51$ \\
Falcated wren-babbler & $\mathrm{NR}$ & $1.5 \pm 80$ & $120 \pm 15$ & $11.2 \pm 52$ \\
Pin-striped tit-babbler & $80.7 \pm 36$ & $97.2 \pm 16$ & $26.7 \pm 26$ & $118.2 \pm 24$ \\
White-vented shama & $6.6 \pm 71$ & $23.7 \pm 32$ & $9.1 \pm 48$ & $30.9 \pm 36$ \\
Palawan flycatcher & $\mathrm{NR}$ & $3.4 \pm 53$ & $30.9 \pm 24$ & + \\
Palawan blue-flycatcher & $8.0 \pm 65$ & $18.1 \pm 21$ & $1.1 \pm 67$ & $29.5 \pm 37$ \\
Mangrove blue-flycatcher & $1.6 \pm 118$ & $2.1 \pm 62$ & $5.2 \pm 31$ & + \\
Citrine canary-flycatcher & $\mathrm{NR}$ & + & $8.8 \pm 44$ \\
\hline
\end{tabular}

${ }^{*}$, total length of transects surveyed; NR, not recorded; +, very low number of encounters

recorded in cultivation at all: Palawan peacock-pheasant Polyplectron napoleonis, Palawan hornbill, red-bellied pitta Pitta erythrogaster, falcated wren-babbler Ptilocichla falcata, Palawan flycatcher Ficedula platenae and citrine canaryflycatcher Culicicapa helianthea. The last of these was also very rarely recorded in early secondary growth. There were few encounters of two species (Palawan flycatcher and mangrove blue-flycatcher Cyornis rufigastra) in old growth.

Ten of the 18 species had their highest density estimates in old growth. Six of these showed a consistent pattern, with density in old growth $>$ advanced secondary growth $>$ early secondary growth $>$ cultivation (Palawan peacock-pheasant, black-backed kingfisher Ceyx erithaca, Palawan hornbill, falcated wren-babbler, white-vented shama Copsychus niger, citrine canary-flycatcher). The remaining four species showed a less consistent pattern but were recorded at highest densities in old growth: Tabon megapode Megapodius cumingii, red junglefowl Gallus gallus, red-bellied pitta and rufous-tailed tailorbird Orthotomus sericeus.

Of the remainder the ashy-headed babbler Malacocincla cinereiceps exhibited a broadly opposite pattern, having its highest density in cultivation and lowest in advanced secondary growth. The others showed no clear patterns, although the highest densities of Palawan flycatcher are in the middle two stages of the habitat gradient, the species being absent from cultivation and rarely encountered in old growth.

\section{Habitat associations of key species}

GLM models were developed for 12 ground-dwelling and understorey species (Table 4). Two variables dominated in the habitat models. Number of trees with $\mathrm{DBH}>160 \mathrm{~cm}$ appeared in models for eight species, with seven of these being associated with areas containing high numbers of large trees (positive $\beta$ coefficients). The strongest indicator of the presence of the majority of ground-dwelling and understorey birds seems not to be an understorey character but an overstorey one. Percentage herb cover appeared in five models but, unlike presence of large trees, birds reacted differently to a dense herb layer, two species having positive and three species having negative $\beta$ coefficients. Five habitat variables appeared in two or fewer models; these were altitude and gradient, numbers of smaller trees, percentage ground cover and number of rattans.

\section{Discussion}

\section{Bird abundance across habitats}

The majority of the understorey and ground-dwelling bird species we studied had highest density estimates in old growth forest. Seven species were strongly associated with areas containing large numbers of big trees, indicating that retention of large trees is an important determinant of the suitability of the understorey for key species on Palawan. These are clearly areas of old growth. Any reduction in extent or quality of this forest type will lead to a reduction in the population size of key species. Those of most concern are the six species that were not recorded in cultivation at all, particularly those that had higher densities in old growth and advanced secondary growth than in early secondary growth, their abundance decreasing along the 
Table 4 Habitat associations of 12 ground and understorey bird species in Puerto Princesa Subterranean River National Park. Figures are $\beta$ coefficients from GLMs with logit links and binomial error distributions, and were retained from minimum adequate models based on AIC minimization (see text for details). Numbers of rattans are not included as this did not feature in the model for any species.

\begin{tabular}{|c|c|c|c|c|c|c|c|c|}
\hline Species & Altitude & Gradient & Mean DBH & $\begin{array}{l}\text { Trees } \\
>160 \mathrm{~cm}\end{array}$ & $\begin{array}{l}\text { Trees } \\
>80-160 \mathrm{~cm}\end{array}$ & $\begin{array}{l}\text { Trees } \\
10-80 \mathrm{~cm}\end{array}$ & Herbs & Ground \\
\hline$\overline{\text { Red junglefowl }}$ & & $+0.072^{\star *}$ & & & & & $+0.025^{*}$ & \\
\hline Palawan peacock-pheasant & & & & $+0.145^{\star}$ & & & & \\
\hline \multicolumn{9}{|l|}{ Palawan hornbill } \\
\hline Black-naped monarch & & & & $+0.124^{\star *}$ & $-0.105^{\star}$ & & & $-0.011^{\star}$ \\
\hline Blue paradise-flycatcher & $-0.003^{*}$ & & & $+0.083^{*}$ & & & & \\
\hline Rufous-tailed tailorbird & & & $-0.009^{*}$ & $+0.096^{*}$ & & & & \\
\hline Ashy-headed babbler & $+0.001^{*}$ & & & $-0.055^{\star}$ & & & & \\
\hline Melodious babbler & & & $+0.012^{*}$ & & & & $+0.024^{*}$ & \\
\hline Pin-striped tit-babbler & & & $-0.007^{\star}$ & $+0.074^{\star}$ & & & & \\
\hline White-vented shama & & & $-0.018^{*}$ & $-0.015^{\star}$ & & & & \\
\hline Palawan blue-flycatcher & & & & $+0.069^{*}$ & & $0.006^{*}$ & $-0.011^{\star}$ & \\
\hline Citrine canary-flycatcher & & & & $+0.141^{\star}$ & & & $-0.029^{*}$ & \\
\hline
\end{tabular}

${ }^{\star} \mathrm{P}<0.05 ;{ }^{*} \mathrm{P}<0.01$

disturbance gradient. This is a pattern recorded in other species from the region (Posa \& Sodhi, 2006; Soh et al., 2006), and these are the species of most conservation concern when great swathes of old growth are lost from landscapes dominated by oil palm plantations (Aratrakorn et al., 2006) or intensive agriculture (Fischer et al., 2007).

Not all species followed this pattern and at least one was recorded at its highest density in each of the other habitat types. Several flycatcher species had highest density estimates in the least disturbed habitats, a pattern often found elsewhere (Thiollay, 1992), but not all species did. The Palawan flycatcher was an exception in not being recorded in either old growth forest or in cultivation, and was uncommon in the other habitats. Our data suggest that it is, to a degree, tolerant of forest alteration, as is the related furtive flycatcher Ficedula disposita from Luzon (BirdLife International, 2009). Similarly, habitat associations differed across the bird community, with individual species' presence seemingly driven by different habitat variables and some species reacting in opposite directions to the same habitat variable. For example, red junglefowl Gallus gallus and melodious babbler Malacopteron palawanense preferred areas with a dense herb layer, whereas three other species preferred habitats with sparse herb layers. Species such as pin-striped tit-babbler Macronus gularis, rufous-tailed tailorbird and black-naped monarch Hypothymis azurea seem to occur across all habitats at similar densities and their future on the island must therefore be reasonably secure. Two endemic babblers, the ashy-headed babbler and the Near Threatened melodious babbler, had highest estimated abundance in cultivation or early secondary growth, and these are clearly tolerant of anthropogenic habitats on Palawan.

There is an expectation that closely related species should be predisposed to react similarly to human impacts (McKinney, 1997). In some congeneric comparisons of species from Borneo and Palawan, species responses were similar. Pin-striped tit-babblers showed an abundance shift between old growth and early secondary growth/cultivation that was similar to that shown between primary and logged forest on Borneo by the fluffy-backed tit-babbler Macronus ptilosus. The wren-babblers also reacted similarly, with falcated on Palawan clearly preferring pristine forests, and Bornean Ptilocichla leucogrammica declining by $>80 \%$ in logged forest (Mead, 2008). However, the positive reaction to forest change by the melodious babbler contrasts sharply with the $90 \%$ density reduction following selective logging found in the congeneric moustached babbler Malacopteron magnirostre and declines in the sooty-capped babbler Malacopteron affine in Borneo (Mead, 2008). The reasons for this difference are unknown (and the habitat changes are different in the two areas) but candidates include differences in diet or, perhaps more likely, breeding ecology. Palawan is a relatively small island that differs from mainland Borneo in its pool of potential nest predators. For example, Borneo has c. 26 species of the order Carnivora (Payne et al., 1985) whereas Palawan has only eight (Esselstyn et al., 2004).

Existing global population estimates for the Vulnerable species in Puerto Princesa Subterranean River National Park are 2,500-9,999 (Palawan peacock-pheasant and Palawan hornbill) and 10,000-19,999 (falcated wren-babbler and Palawan flycatcher; BirdLife International, 2010). Land cover interpretation (DENR-NAMRIA \& JAFTA, $1992-2000)$ for the whole of Palawan $\left(14,303 \mathrm{~km}^{2}\right)$, excluding $1,616 \mathrm{~km}^{2}$ of high-elevation forests, indicates there may be $2,995 \mathrm{~km}^{2}$ of old growth forest, $6,049 \mathrm{~km}^{2}$ of secondary growth forest and $3,643 \mathrm{~km}^{2}$ of cultivated land and built-up areas. Simple extrapolation of our population densities from the Park would therefore clearly yield much higher island-wide populations than the current global estimates. 
For example, Palawan hornbill could be predicted to have a population of almost 59,000 individuals in old growth alone (given a population density of $19.6 \mathrm{~km}^{-2}$ over an area of $2,995 \mathrm{~km}^{2}$ ). While we suggest that island-wide populations are likely to be considerably larger than currently thought, there are several important issues that make simple extrapolations unwise. The satellite images on which the islandwide figures are based were not concurrent with the bird surveys, there is no indication that the habitat classifications used by DENR-NAMRIA \& JAFTA (1992-2000) are comparable with our own classifications and, perhaps most importantly, we cannot realistically expect densities within this small portion of the island to reflect abundance elsewhere (Jones et al., 2003). Differences in altitude, geology and climate, along with patterns of current and historical land use and direct exploitation, all mean that inferences about densities from our study should be limited to within the sampled area (Buckland et al., 2008).

\section{Management implications}

Puerto Princesa Subterranean River National Park, like other protected areas in the Philippines, is under pressure from various land-use practices, including the clearance of new areas for agriculture, gathering of non-timber forest products such as rattan, and other alterations to natural vegetation for human needs (Mallari et al., 2001). National and local policies on biodiversity conservation and forest protection in the Philippines recognize both natural and anthropogenic habitats as key determinants of protected area status and management zones and regimes. There is a bias in Philippine regulations towards bestowing protection status on forests at high elevations $\left(>_{1,000} \mathrm{~m}\right)$ and on steep slopes $(\geq 18 \%)$, rather than determining management on the basis of forest structure and habitat complexity as a surrogate for biodiversity conservation value. Our results show that management should ensure that extent and quality of old growth and advanced secondary growth are not reduced. Given that current protection status is skewed towards forests at higher altitudes and on steeper slopes, we recommend revision of the zoning regimes so as to align protection status more appropriately with biodiversity value and represent more fully all naturally occurring habitats on Palawan.

Puerto Princesa Subterranean River National Park covers only c. $1.4 \%$ of the total land area of Palawan, and thus advances in its management are dwarfed by the gap in the coverage of protected areas across Palawan as a whole. Although Palawan has $>50 \%$ forest cover there is a threat of extensive loss through logging and mining of the remaining old growth in the lowlands, which are mostly not protected (ESSC, 2009). Deforestation rates reached $11 \%$ between 2000 and 2005, the second highest in the country. Based on the December 2008 data of the Mines and Geosciences Bureau and the Palawan Provincial Environment and Natural Resource Office, there are seven Mineral Production Sharing Agreements and nine Small Scale Mining Permits already issued and 354 mining applications pending covering $6,510 \mathrm{~km}^{2}$ of land within the province.

Our study has demonstrated the importance of relatively mature forest for many of Palawan's endemic birds and we believe there is an urgent need to strengthen the protected area network in Palawan by expediting the declaration and establishment of appropriate conservation and management systems of incipient protected areas, namely Mt Mantalingajan, Mts Victoria-Anepahan, San Vicente forest blocks and El Nido-Taytay forests (Anda \& Tabangay, 2004). These areas cover the largest tracts of undisturbed lowland forest on the island, and together constitute $27 \%$ of the total land area. Included in these are areas such as Victoria-Anepahan and parts of Narra municipality, which hold populations of many lowland endemic bird species discussed here plus those of the Critically Endangered Philippine cockatoo Cacatua haematuropygia (Collar et al., 1999).

At the outset of this study there was recognition of the urgent need to revise the management plan of Puerto Princesa Subterranean River National Park. In response to this need an agreement was struck with its Protected Area Management Board that the results of this study would be presented to the Park authorities and other stakeholders, and revisions of the management plan are consequently now under way.

\section{Acknowledgements}

This article is one of the outputs of the World Pheasant Association-Manchester Metropolitan University project to build conservation capacity of students, key figures within the local community and NGO conservationists in Palawan, funded by the Critical Ecosystem Partnership Fund, Rufford Small Grants for Nature Conservation, Mohamed bin Zayed Species Conservation Fund, and The North of England Zoological Society at Chester Zoo. We also thank the Protected Area Management Board and staff of Puerto Princesa Subterranean River National Park, Bagtik Survey Team, Don de Alban, Palawan Council for Sustainable Development Staff and Department of Environment and Natural Resources Region 4 for the technical, administrative and logistical support during this study and the community consultations.

\section{References}

A калке, H. (1974) A new look at statistical model identification. IEEE Transactions on Automatic Control, Au-19, 716-722. Anda, R.D. \& Tabangay, J.G. (2004) Surublien: Strategies to Conserve Palawan's Biodiversity. Provincial Government of 
Palawan, PCSDS, DENR-MIMAROPA Region 4, Palawan NGO Network, Inc., and CI-Philippines, Puerto Princesa City, Philippines. Aratrakorn, S., Thunhikorn, S. \& Donald, P.F. (2006) Changes in bird communities following conversion of lowland forest to oil palm and rubber plantations in southern Thailand. Bird Conservation International, 16, 71-82.

Barlow, J., Peres, C.A., Henriques, L.M.P., Stouffer, P.C. \& Wunderle, J.M. (2006) The responses of understorey birds to forest fragmentation, logging and wildfires: an Amazonian synthesis. Biological Conservation, 128, 182-192.

BirdLife International (2003) Saving Asia's Threatened Birds: A Guide for Government and Civil Society. BirdLife International, Cambridge, UK.

BirdLife International (2009) Species Factsheet: Ficedula platenae. Http://www.birdlife.org [accessed 15 March 2010].

BirdLife International (2010) Data Zone. Http://www.birdlife.org/ datazone [accessed 29 October 2010].

BLAKE, J.G. (1992) Temporal variation in point counts of birds in a lowland wet forest in Costa Rica. Condor, 94, 265-275.

Buckland, S.T., Anderson, D.R., Burnham, K.P., LaAke, J.L., Borchers, D.L. \& Thomas, L. (2001) Introduction to Distance Sampling: Estimating Abundance of Biological Populations. Oxford University Press, Oxford, UK.

Buckland, S.T., Marsden, S.J. \& Green, R.E. (2008) Estimating bird abundance: making methods work. Bird Conservation International, 18, S91-S108.

Collar, N.J., Mallari, N.A.D. \& Tabaranza, JR, B.R. (1999) Threatened Birds of the Philippines. Haribon/BirdLife and Bookmark Inc., Makati City, Philippines.

DENR-NAMRIA \& JAFTA (Department of Environment and Natural Resources/National Mapping and Resource Authority, \& Japan Forest Technology Association) (1992-2000) Land Cover Statistics 1993-2000: Palawan Forest Cover Map. DENR-FMB, Quezon City, Philippines.

DENR-PAWB (Department of Environment and Natural ResourcesProtected Areas and Wildlife Bureau), CI-Philippines, \& NEDA (National Economic and Development Authority) (2004) Philippine Biodiversity Multimedia Resource (DVD-ROM). Department of Environment and Natural Resources-Protected Areas and Wildlife Bureau, Conservation International FoundationPhilippines, National Economic and Development Authority, Quezon City, Philippines.

Diaz, I.A., Armesto, J.J., Reid, S., Sieving, K.E. \& Willson, M.F. (2005) Linking forest structure and composition: avian diversity in successional forests of Chiloé Island, Chile. Biological Conservation, 123, 91-101.

Dickinson, E.C., Kennedy, R.S. \& Parkes, K.C. (1991) The Birds of the Philippines: An Annotated Check-List. British Ornithologists Union (Check-list 12), Tring, UK.

ESSC (Environmental SCience for Social Change) (2009) 2002 Forest Cover of the Philippines Series Number 2514 (map 1:250,00o). Quezon City, Philippines. Http://essc.org.ph/component/option,com_wrapper/Itemid,109/ [accessed 7 November 2009].

Esselstyn, J.A., Widmann, P. \& Heaney, L.R. (2004) The mammals of Palawan Island, Philippines. Proceedings of the Biological Society of Washington, 117, 271-302.

Fischer, J., Lindenmayer, D.B., Blomberg, S.P., MontagueDrake, R., Felton, A. \& Stein, J.A. (2007) Functional richness and relative resilience of bird communities in regions with different land use intensities. Ecosystems, 10, 964-974.

Fitzherbert, E.B., Struebig, M.J., Morel, A., Danielsen, F., Brühl, C.A., Donald, P.F. \& Phalan, B. (2008) How will oil palm expansion affect biodiversity? Trends in Ecology \& Evolution, 23, 538-545.
IUCN (2001) 2001 IUCN Red List Categories and Criteria v. 3.1. IUCN, Gland, Switzerland [http://www.iucnredlist.org/technicaldocuments/categories-and criteria/2001-categories-criteria, accessed 29 October 2010].

IUCN (2010) IUCN Red List of Threatened Species v. 2010.4. Http:// www.iucnredlist.org [accessed 29 October 2010].

Jones, M.J. (1998) Study design. In Expedition Field Techniques: Bird Surveys (eds C. Bibby, M. Jones \& S. Marsden), pp. 15-35. Expedition Advisory Centre. Royal Geographic Society, London, UK.

Jones, M.J., Marsden, S.J. \& Linsley, M.D. (2003) Effects of habitat change and geographical variation on the bird communities of two Indonesian islands. Biodiversity and Conservation, 12, 1013-1032.

KARR, J.R. (1981) Surveying birds in the tropics. Studies in Avian Biology, 6, 548-553.

LAmbert, F.R. \& Collar, N.J. (2002) The future for Sundaic lowland forest birds: long-term effects of commercial logging and fragmentation. Forktail, 18, 127-146.

LeE, D.C. \& MARSDEN, S.J. (2008) Adjusting count period strategies to improve the accuracy of forest bird abundance estimates from point transect distance sampling surveys. Ibis, 150, 315-325.

Mallari, N.A.D. (2009) Maximising the value of ecological and socio-economic data in support of conservation planning for key understorey bird species in Palawan, Philippines. PhD thesis. Manchester Metropolitan University, Manchester, UK.

Mallari, N.A.D., Tabaranza, JR, B.R. \& Crosby, M.J. (2001) Key Conservation Sites in the Philippines: A Haribon Foundation and BirdLife International Directory of Important Bird Areas. Bookmark Inc., Manila, Philippines.

Marsden, S.J., Symes, C.T. \& Mack, A.L. (2006) The response of a New Guinean avifauna to conversion of forest to small-scale agriculture. Ibis, 148, 629-640.

MCKinney, M.L. (1997) Extinction vulnerability and selectivity: combining ecological and paleontological views. Annual Review of Ecology and Systematics, 28, 495-516.

$\mathrm{MEAD}, \mathrm{C} .(2008)$ The effects of logging on understorey birds in Borneo. $\mathrm{PhD}$ thesis. Manchester Metropolitan University, Manchester, UK.

Payne, J., Francis, C.M. \& Phillipps, K. (1985) A Field Guide to the Mammals of Borneo. Sabah Society and WWF Malaysia, Kota Kinabalu, Malaysia.

Peh, K.S.H., De Jong, J., Sodhi, N.S., Lim, S.L.H. \& Yap, C.A.M. (2005) Lowland rainforest avifauna and human disturbance: persistence of primary forest birds in selectively logged forests and mixed-rural habitats of southern Peninsular Malaysia. Biological Conservation, 123, 489-505.

Posa, M.R.C., Diesmos, A.C., Sodhi, N.S. \& Brooks, T.M. (2008) Hope for threatened tropical biodiversity: lessons from the Philippines. BioScience, 58, 231-240.

Posa, M.R.C. \& Sodhi, N.S. (2006) Effects of anthropogenic land use on forest birds and butterflies in Subic Bay, Philippines. Biological Conservation, 129, 256-270.

R Development Core Team (2009) R: A Language and Environment for Statistical Computing. R Foundation for Statistical Computing, Vienna, Austria. Http://www.R-project.org [accessed 29 October 2010].

SCALES, B.R. \& MARSDEN, S.J. (2008) Biodiversity in small-scale tropical agroforests: a review of species richness and abundance shifts and the factors influencing them. Environmental Conservation, $35,160-172$.

Soh, M.C.K., SodHI, N.S. \& Lim, S.L.H. (2006) High sensitivity of montane bird communities to habitat disturbance in Peninsular Malaysia. Biological Conservation, 129, 149-166. 
Thiollay, J.M. (1992) Influence of selective logging on bird species diversity in a Guianan rain-forest. Conservation Biology, 6, 47-63.

Thomas, L., Laake, J.L., Strindberg, S., Marques, F.F.C., Buckland, S.T., Borchers, D.L. et al. (2006) Distance 5.o. Release 2. Research Unit for Wildlife Population Assessment, University of St Andrews, St Andrews, UK.

UNDP-GEF-SGP (United Nations Development ProgrammeGlobal Environment Facility-Small Grants Programme) (2003) Conservation of Biodiversity of Puerto Princesa Subterranean River National Park. Unpublished report to UNDP-GEF-SGP, UN Foundation and Community Management of Protected Areas Conservation Project, Manila, Philippines.

\section{Biographical sketches}

Neil Aldrin D. Mallari manages the conservation programme of Fauna \& Flora International in the Philippines. He works with local conservation NGO partners to protect threatened species and ecosystems through community-led initiatives. NigEL J. Colla R works on threatened bird species, running projects in Angola and Ethiopia. DAVID LEE leads the research and conservation component of the Harapan Rainforest ecosystem restoration initiative, including biodiversity monitoring to inform effective forest management and training in conservation field methods. PHILIP MCGowaN is concerned with ensuring that no species of Galliformes goes extinct and balancing the needs of all 300 Galliformes species with the communities that live alongside them. Roger Wilkinson's main interests are in conservation biology, animal behaviour, ecology and ornithology. Amongst other things he manages Chester Zoo's Philippines Field Conservation Programmes. Stuart Marsden's work relates to the effects of land use and other environmental change on tropical wildlife. He is particularly interested in ecological study methods. 